\author{
Magdalena Syrkiewicz-Świtała ${ }^{1}$, Marlena Kotlarek² \\ Śląski Uniwersytet Medyczny w Katowicach \\ Wydział Zdrowia Publicznego w Bytomiu \\ 1e-mail: mswitala@sum.edu.pl \\ ²e-mail: marlena.kotlarek@gmail.com
}

\title{
The importance of social media marketing in promoting health in the opinion of inhabitants of Gliwice
}

\section{Codes JEL: M3, I1}

Keywords: social media, social media marketing, health promotion, public health

Summary. Pro-health messages can be propagated through different media; one of them is social media. The objective of the paper is defining the importance of social media marketing in promoting health in the opinion of the inhabitants of Gliwice. The paper uses the qualitative questionnaire survey conducted in late January and February 2017 among 200 adult inhabitants of Gliwice. Statistical analysis of collected material was developed through the program Statistica 10.0, StatSoft and Microsoft Excel. The analysis uses the Pearson chi-square test with the assumed significance level $\mathrm{p}<0.05$. The vast majority of respondents use the Internet as a source of health information. Social media marketing is very important for almost a quarter of the population surveyed due to their active presence in social networks and thus it can be a useful tool in health promotion activities.

\section{Introduction}

Health promotion activity is oriented towards prophylaxis of addictions, diseases of affluence and chronic diseases which nowadays affect an increasing number of people (Wrona-Polańska, 2006). Among the key aims of health promotion the ones which deserve mentioning are: everyday physical activity, a bal- 
anced diet and stress handling (Aktywność..., 2016). Currently, the most common tool of health promotion is health education whose main goal is to create conscious attitudes and behaviors, which then help obtain and maintain good health (Hagel, 2011). A characteristic feature of social health campaigns is inducing a selected social group to initiate modification of their behavior and habits to achieve expected results, facilitating the state of good health. Mass media play a supportive role in this area. They constitute a main source of current information, which covers also the sphere of health (Evans, 2006; Syrkiewicz-Świtała, Holecki, Wojtynek, 2014).

Health promoting announcements may be disseminated by means of various media, including social media. Health campaigns promoting pro-health behavior run in social media represent an innovative approach. Up until now there have already existed many forms of transmitting the scientific-didactic message on health issues, aimed to correct health behaviors and lifestyles accepted by society. Tools of marketing communication like: outdoor advertising, commercial spots, radio and television broadcasts, events or more traditional sources of information (sticker art, posters, brochures) enable active dialogue between the educator-sender and the beneficiary-receiver of information. All these forms are intended to send in an effective message, propagating pro-health activities, yet they lack a complete personal dimension of message transmission. Along with the development of modern technology and ubiquitous informatization, the receivers' expectations regarding the form and quality of information sources are changing.

The increased popularity trend of the Internet usage, including social media as one of main communication means, repeatedly influences its employment and utilization for the sake of promoting pro-health behavior (Amrita, Biswas, 2013). Social media realize efficient and effective promotion, often based on information which is attractive to its receiver (Whittemore, Jeon, Grey, 2013). Nowadays, social media is the fastest and most effective tool of direct communication (Syrkiewicz-Świtała, Świtała, 2012). Therefore, attention should be paid to the universality of social media, manifesting itself in the population's ability to influence the spread of information in relatively short time and long range (Fabjaniak-Czerniak, 2012).

Social media, covering health issues and preventive actions devoted to elimination of pathogenic factors, constitute a new sphere of analysis and study for experts in the field. Interpretation of scrutiny results shows that generators of social media websites most often release information concerning disease symptoms, medications and treatment methods. Moreover, a growing trend in attractiveness of propagating healthy lifestyle by means of social media has been observed (Hanik, Stellefson, 2011). This became a prerequisite to handle the hereby research problem whose main purpose was to determine the role of 
social media marketing in health promotion as perceived by the inhabitants of Gliwice.

\section{Material and method}

A survey involving a qualitative questionnaire was conducted at the turn of January and February 2017 among the inhabitants of Gliwice. The research covered a group of 200 respondents aged over 18. The background survey was conducted by means of a proprietary questionnaire, traditionally printed on paper forms and distributed in the main hall of the PKP railway station in Gliwice. The survey form consisted of 29 closed questions. The questionnaire was divided into two parts. The first section covered demographics, allowing personal identification of respondents. The second section was devoted to main data, enabling realization of the purpose of the study.

The statistical analysis of the material gathered was carried out using the Statistica 10.0 package by StatSoft and Microsoft Excel. For statistical analysis the Pearson's chi-square test was employed to assess whether the dependencies observed in the research sample were an effect of a more general regularity in the general population or a random output only. The test is applied when variables of qualitative and not quantitative character are used for the analysis. The result of the statistical test was the so called test probability (p), whose low values proved the statistical significance of considered differences. The statistical significance in this analysis was assumed $\mathrm{p}<0.05$.

\section{Results}

A total of 200 inhabitants of Gliwice took part in the research. Out of the group as a whole, $125(62.5 \%)$ were female and $75(37.5 \%)$ were male. The largest group among surveyed persons were people with higher education $(46.5 \%$; 93). The next group of surveyed people $(36.5 \%$; 73) reported secondary education. A further $12 \%$ (24) of the respondents were people who had graduated from vocational schools. The smallest proportion of the respondents constituted those with primary education $(5 \% ; 10)$. The age profile of the people surveyed showed that the respondents were of different age groups which varied in number. $47 \%$ (94) of the respondents were people aged 18-24, whereas the respondents in the age group 25-34 made $22.5 \%$ of all the inhabitants surveyed (45). Then, the people aged 35-44 and 45-54 years old were $11.5 \%$ (23) and $9.5 \%$ (19) respectively. The least numerous representative groups in this research were formed by the respondents who ranged in age from 55 to 64 years old $(5.5 \% ; 11)$ and those older than 64 years of age $(4 \% ; 8)$.

The population surveyed represented in majority $(65 \% ; 130)$ a group of very active social media/Internet users who acknowledged everyday use of this 
tool. In turn, the use of social media several times a week was reported by $17.5 \%$ (35) of the respondents. The group of virtual reality users who use it once a week constituted $11.5 \%$ of those surveyed (23). Only a small group of the respondents $(6 \% ; 12)$ confirmed using social media less frequently than once a month. The most popular social media types among the respondents were, in a decreasing order: social networks like Facebook, Nasza-Klasa, Grono (51.5\%; 103); Internet browser $(23.5 \%$; 47$)$; discussion forums $(7 \% ; 14)$ and expert social media $(6 \%$; 12). By contrast, the lesser popularity among the research group was ascribed to: medical entities websites $(5 \% ; 10)$, video streaming services $(4 \% ; 8)$ and blogs and microblogs $(3 \% ; 6)$. The Internet services with higher number of hits among the responders were: ,abcZdrowie.pl” (27.5\%; 55), ,znanylekarz.pl” (17\%; 34), „zdrowie.onet.pl” (14\%; 28) and „poradnikzdrowie.pl” (12\%; 24). The analysis confirmed the less popular health services to be: zdrowieifitness.wp.pl" (9\%; 18), „doz.pl” (6\%; 12), ,zdrowie.gazeta.pl” (5.5\%; 11), „biomedical.pl” (3.5\%; 7), „rynekmedyczny.pl” $(3.5 \% ; 7)$ and „przychodnia.pl” (2\%; 4). None of the respondents, in contrast, was using „test-zdrowia.pl” $(0 \% ; 0)$.

91.5\% (185) of the answerers declared that they used information on health and prophylaxis sourced from the Internet at least once in their life. Answering the question "what topics related to health do you most often browse in social media?", the people surveyed indicated searching above all for news on suggestions regarding a healthy diet $(18 \% ; 36)$ and dosage/impact of the medicaments on human organism $(14 \% ; 29)$. Topics of secondary importance, searched online, included: medical diagnosis $(9.5 \% ; 19)$, available medical treatments $(8.5 \% ; 17)$ and information on diet supplementation $(7.5 \% ; 15)$. In turn, the issues of lesser importance to the research group were related to: signs and symptoms over the course of the disease $(7 \% ; 14)$, intimate life $(4 \% ; 8)$, medical procedures $(3.5 \% ; 7)$, presentation of alternative medicine practice $(2.5 \% ; 5)$, mental health, including problems of stress and depression $(2 \% ; 4)$, ways of coping with addictions $(2 \% ; 4)$ and information directly related to allergies $(1.5 \% ; 3)$. Only a few $(1 \% ; 2)$ of all the respondents admitted to browsing information online - most frequently on prevention of diseases and recommended screening tests. The areas of interests to the male and female respondents which they searched for online were statistically significantly different $(p=0.001)$. Women more often than men were interested in healthy diets, medicaments, allergies, diagnosis and treatment, whereas men more frequently searched online for information on active lifestyle, diet and vitamin supplements, medical procedures, addiction therapies, sexual life, mental health, nonconventional medicine, disease prevention, screening tests, as well as facts on disease stages and development. The issues searched for online were similar among persons with different educational background. No statistically significant differences were found in this respect $(p=0.372)$. However, the statistical 
significance was observed in regard to age $(\mathrm{p}=0.002)$. Younger respondents searched more frequently for information on a healthy diet, active lifestyle, diet and vitamin supplements, and medical diagnostics. Older people, in turn, more frequently looked for information on the effects of medicines, addiction therapies, sex life, alternative medicine, prophylaxis and screening tests.

In the case of health problems, $40 \%$ (80) of the respondents as a first resort searched online for basic information about the issue. The next option was seeking a specialist doctor, to which $36 \%$ (72) of the inhabitants of Gliwice under study admitted. Experience and knowledge possessed by friends/ acquaintances still seems to be reliable for the population under research, as $14 \%$ (28) of the respondents declared. On the other hand, professional expertise derived from books and specialist journals as a first source of information to verify initial disease symptoms was indicated by merely $6 \%$ (12) of all the responders. The fewest of the people surveyed preferred traditional media like television $(3 \% ; 6)$ and radio $(1 \% ; 2)$ as the centre of initial information on first signs and symptoms of the upcoming health problems. This dependency was statistically significant $(\mathrm{p}=0.008)$. Women, as first resort, searched for information online or consulted a specialist. Very rarely did they turn to sources like books, articles, radio or television. Men also tended to use information available on the Internet or obtained from a physician, yet, more often than women, they checked information in books, journal articles, TV and radio. No relevant statistical differences were found in terms of the first source of information the research group used and the level of their education. The interrelation was not statistically significant $(p=0.338)$. Sources which the respondents experiencing health problems made use of at first varied depending on their age. The research showed that younger persons, more often than the elders, benefited from information available online; the same tendency was observed in reference to consulting a medical specialist. As a result, older people more often pinpointed books, articles, radio and television as sources of information, and similarly, they tended to consult their friends and people they knew.

When asked about the main purpose of their Internet usage, $42.5 \%$ (85) of the respondents admitted the primary goal was to find information on the address of a healthcare facility whose services they intend to use in the nearest future. The people surveyed further indicated the main reason for browsing the web was to find opinions about a given physician or medical entity $(27.5 \% ; 55)$. A further $11 \%$ (22) of the respondents pointed out using the Internet to obtain medical advice and 9.5\% (19) of those interviewed declared they needed information related to expected waiting time for a medical appointment. Other mentioned motives for checking posts in cyberspace were issues related to: reception of medical tests' results in an e-mail $(4.5 \%$; 9), requesting doctor's visits $(3 \% ; 6)$ and ordering prescriptions $(2 \% ; 4)$. The reason for using the Internet by 
men and women was statistically significantly different $(\mathrm{p}=0.006)$. Women more frequently searched for the address of a medical entity or checked opinions on a given doctor online. Men more often ordered prescriptions, collected test results, obtained medical advice and checked the expected waiting time for a doctor's appointment on the Internet. There was a statistically significant difference in the reason behind using the web by people in various age groups ( $p<0.001$ ). The younger most often looked for the address of healthcare facilities and verified feedback on specific doctors or medical entities, while older respondents ordered prescriptions and medical appointments online, obtained doctor's advice and checked the expected waiting time for an appointment more frequently. No statistically significant difference $(\mathrm{p}=0.155)$ was revealed in the most common reasons for the Internet usage in terms of the respondents' education.

The research determined also an analysis of subjective assessments regarding most common health issues in health promoting campaigns. The largest group of people surveyed approved of running campaigns, directly promoting healthy lifestyle, including rational nutrition and active way of life $(35 \% ; 70)$. Further most often mentioned problems were: cancer prevention $(22 \% ; 44)$, the fight against overweight and obesity $(17 \%$; 34$)$, and female population health $(11 \% ; 22)$. Problems addressed on smaller scale were, according to the respondents: actions promoting road traffic safety $(7.5 \% ; 15)$, prevention of diseases affecting circulatory system $(4.5 \%$; 9$)$ and the fight against malnutrition among children $(3 \% ; 6)$.

When asked about credibility of social media as a main source of information on health and diseases, the respondents of the hereby study most often pointed out its medium level of reliability $(45.5 \%$; 91). Then, those who regarded social media as credible were $28 \%$ (56). On the contrary, $12 \%$ (24) of the people surveyed assessed social media as an unreliable source of information on health matters. The number of respondents for whom social media constitute a rudimentary database, verifying the aspect of physiological state of the individual, reached $7.5 \%$ (15) and 7\% (14) of the 200 inhabitants surveyed maintained that there was a complete lack of pertinence and reliability of information provided by social media on topics of health and diseases. Opinions of the women and men surveyed on social media as a comprehensive source of information on health/disease did not significantly vary statistically $(\mathrm{p}=0.297)$. They did, however, depending on their level of education $(\mathrm{p}=0.028)$ and age $(p=0.011)$. The higher the education level or the older the respondents (over 50 years of age), the less credible the social media as a source of information on health issues were considered by the respondents.

$43.5 \%$ (87) of the inhabitants surveyed declared that they rarely use information available in social media to diagnose existing symptoms. $22.5 \%$ (45) of 
the respondents opted for frequent use of information obtained from social media on the signs and symptoms foreshadowing pathogenic processes. For $16 \%$ (32) of the 200 answerers, the above mentioned source of information was of little value as a database including useful information on diagnosis of the occurring symptoms. 9.5\% (19) of the respondents declared that they never use social media to diagnose the symptoms of their disease or ailments. Only by the $8.5 \%$ (17) of the people surveyed social media were perceived as a valuable source of information. The frequency of using information available in social media to diagnose the symptoms varied between the men and women surveyed. The difference was significant statistically $(p=0.005)$. Women used information from social media more often than men. In terms of education level no statistically significant differences were observed $(\mathrm{p}=0.121)$. These differences were found, however, between the age groups under research $(\mathrm{p}=0.010)$. Younger persons utilized information from social media more frequently.

$31.5 \%$ (63) of the people surveyed declared that studying information on health issues published on the Internet, including social media, directly determines their visit at the doctor's office for a checkup. A further $26 \%$ (52) of all the respondents saw such a solution as probable. $22 \%$ (44) of the respondents stated that information from the Internet and social media is not considered plausible to verify their physiological state in order to determine whether consulting a specialist is necessary or not. Next $13 \%$ (26) of the answerers admitted that health information obtained from cyberspace would encourage them to visit a doctor's office to verify it. Merely $7.5 \%$ (15) of the respondents declared unequivocal distrust in the Internet forum posts on health and diseases. No statistically meaningful differences were observed in this respect as the respondents' gender was considered $(\mathrm{p}=0.581)$. The significant differences appeared in terms of the respondents' education level $(p=0.018)$ and age $(p=0.039)$. Higher education or increased age were accompanied by decreased frequency of arranging a doctor's appointment as a result of becoming acquainted with information from the Internet/social media.

A large number of respondents attributed medium suitability to social media in extending knowledge on pro-health behavior (44\%; 88), whereas $23.5 \%$ (47) of those surveyed perceived social media as a valuable and accessible source of information, enabling people to broaden their knowledge on health issues. $16.5 \%$ (33) of all the people surveyed held the view that social media have little impact as means of disseminating promotional and educational content, supporting pro-health activities. 9.5\% (19) of the respondents indicated a complete lack of usability of social media to deepen one's knowledge on health. On the contrary, 6.5\% (13) of the respondents were a group of social media followers who notice vital importance of this channel of communication, enabling individuals to acquire necessary competence to obtain and maintain 
their health in a good condition. Extending one's knowledge on pro-health behavior by using social media showed statistically significant difference in terms of gender $(\mathrm{p}=0.010)$, level of education $(\mathrm{p}=0.018)$ and age $(\mathrm{p}<0.001)$ of the respondents. This was declared more often by men than women, by inhabitants over 50 years of age, and by those with secondary education.

\section{Summary}

The vast majority of respondents use the Internet as a source of information on health concerns. In the research group, social media constitute one of the major channels of communication and distribution of information on the following aspects related to health: implementation of a balanced diet, leading an active lifestyle and facts on dosage/effects of the medicaments. As the main reasons behind the quest for information on health in social media, the respondents mentioned: localization of healthcare providers, verification of patient reviews and ranks of a given physician/entity, obtaining medical advice from doctors, information on expected waiting time for a medical appointment, verification of individual or family members' state of health and interpretation of medical test results. Social media marketing is of high importance to one fourth of the population surveyed due to their active presence in social networks. Thus, it may become a useful tool for activities in the field of health promotion, as well as enable respondents to extend their frame of knowledge and develop the competence in health. For the majority of respondents, the social media publishing information on health promotion constitute a reliable medium to exchange information on health and diseases. According to over 50\% of the group surveyed, this medium is characterized by credibility of presented content inducing the population to take actions for the sake of health. Social media form an effective instrument which can be employed to propagate pro-health behavior among the group under study. Promotional actions and campaigns run by means of social media may become a compatible counterpart for the remaining activities in health promotion.

\section{Bibliography}

Aktywność fizyczna $i$ sport (13.08.2016). Ministerstwo Zdrowia. Retrieved from: www.mz.gov.pl/zdrowie-i-profilaktyka/zdrowie-matki-i-dziecka/zdrowie-ucznia/aktywno sc-fizyczna-i-sport/.

Amrita, Biswas, D. (2013). Health care social media: expectations of users in a developing country. Medicine 2.0, 2 (2). Retrived from: www.medicine20.com/2013/2/e4/ (4.02.2015).

Evans, W.D. (2006). How social marketing works in health care. BMJ, 332 (7551), 1207-1210.

Fabjaniak-Czerniak, K. (2012). Internetowe media spolecznościowe jako narzędzie public relations. In: K. Kubiak (ed.), Zarządzanie w sytuacjach kryzysowych niepewności (p. 184) Warszawa: WSPW.

Hagel, G. (2011). Edukacja zdrowotna i ekologiczna. Szczecin: SSWCB. 
Hanik, B., Stellefson, M. (2011). E-health literacy competencies among undergraduate education students. A preliminary study. International Electronic Journal of Health Education, 14 (47).

Syrkiewicz-Światła, M, Holecki, T, Wojtynek, E. (2014). Znaczenie mass mediów w promocji zdrowia. Medycyna Ogólna i Nauki o Zdrowiu, 20 (2), 171-176.

Syrkiewicz-Świtała, M., Świtała, R. (2012). Social media marketing jako współczesna koncepcja komunikowania się jednostek ochrony zdrowia z otoczeniem. Zeszyty Naukowe Politechniki Częstochowskiej. Zarzadzanie, 5, 87, 86-94.

Whittemore, R., Jeon, S., Grey, M. (2013). An Internet Obesity Prevention Program for Adolescents. J. Adolesc. Health, 52, 439-447.

Wrona-Polańska, H. (2006). Health- its psychological indicators and ways of its promotion and suport. Sztuka Leczenia, 1-2 (13), 19-31. Retrieved from: www.sztukaleczenia.pl/pub/ 2006/1-2/zdrowie-psychologiczne_wyznaczniki.pdf.

\section{Znaczenie social media marketingu w promocji zdrowia w opinii mieszkańców Gliwic}

Słowa kluczowe: social media, social media marketing, promocja zdrowia, zdrowie publiczne

Streszczenie. Komunikaty prozdrowotne mogą być propagowane za pośrednictwem różnych mediów - jednym z nich są media społecznościowe. Celem pracy jest określenie znaczenia social media marketingu w promocji zdrowia w opinii mieszkańców Gliwic. Wykorzystano badanie kwestionariuszowe o charakterze jakościowym przeprowadzone na przełomie stycznia i lutego 2017 roku wśród 200 pełnoletnich mieszkańców Gliwic. Analizę statystyczną zebranego materiału opracowano za pośrednictwem programu Statistica 10.0. StatSoft oraz Microsoft Excel. W analizie wykorzystano test chikwadrat Pearsona $\mathrm{z}$ przyjętym poziomem istotności statystycznej $\mathrm{p}<0,05$. Wnioski przeważająca większość badanych korzysta $\mathrm{z}$ internetu jako źródła informacji na temat zdrowia. Social media marketing ma duże znaczenie dla prawie jednej czwartej badanej populacji $z$ uwagi na ich aktywność $w$ sieciach społecznościowych i przez to może stanowić użyteczne narzędzie w działaniach z zakresu promocji zdrowia.

Translated by Magdalena Syrkiewicz-Świtała

\section{Cytowanie}

Syrkiewicz-Świtała, M., Kotlarek, M. (2017). The importance of social media marketing in promoting health in the opinion of inhabitants of Gliwice. Marketing i Zarzadzanie, 1 (47), 353-361. DOI: 10.18276/miz.2017.47-33 